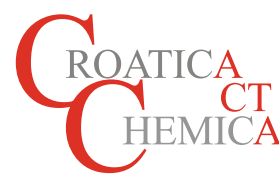

\title{
Content of Bioactive Constituents and Antioxidant Potential of Galium L. Species
}

\author{
Maja Friščić, ${ }^{1, *}$ Maja Štibrić Baglama, ${ }^{2}$ Milenko Milović, ${ }^{3}$ Kroata Hazler Pilepić, ${ }^{1}$ Željan Maleš
}

\author{
1 University of Zagreb, Faculty of Pharmacy and Biochemistry, Department of Pharmaceutical Botany, Schrottova 39, HR-10000 Zagreb, Croatia \\ 2 ZU Ljekarne Pučko, Vladimira Nazora 25A, HR-44320 Kutina, Croatia \\ 3 Antun Vrančić Grammar School, Put Gimnazije 64, HR-22000 Šibenik, Croatia \\ * Corresponding author's e-mail address:mfriscic@pharma.hr
}

RECEIVED: June 1, 2018 * REVISED: July 5, 2018 * ACCEPTED: July 9, 2018

\begin{abstract}
Qualitative phytochemical analyses of eight species from the genus Galium (G. corrudifolium, G. cruciata, G. divaricatum, G. Iucidum, G. mollugo, G. palustre, G. parisiense, and G. verum), followed by spectrophotometric evaluation of their total phenolic, flavonoid and iridoid content, as well as antiradical capacity, were conducted. G. cruciata contained the greatest amount of total phenolics (111.00 mg gallic acid equivalents $\mathrm{g}^{-1}$ dry extract), while $\mathrm{G}$. verum had the greatest amount of flavonoids ( $23.11 \mathrm{mg}$ quercetin equivalents $\mathrm{g}^{-1} \mathrm{dry}$ extract) and iridoids (461.30 mg aucubin equivalents $\mathrm{g}^{-1}$ dry extract). The best antioxidant (antiradical) activity was shown by $\mathrm{G}$. $\mathrm{cruciata}\left(\mathrm{IC} \mathrm{C}_{50}(\mathrm{ABTS})=30.30 \mathrm{\mu g} \mathrm{mL}^{-1}\right.$; $I_{50}(\mathrm{DPPH})=27.62 \mu \mathrm{g} \mathrm{mL} \mathrm{L}^{-1}$ ), followed by G. divaricatum, G. verum and G. palustre. The same species were rich in various bioactive constituents and would be appropriate for inclusion in further investigations considering their biomedical potential.
\end{abstract}

Keywords: Galium, phytochemical screening, secondary metabolites, bioactive compounds, antioxidant activity.

\section{INTRODUCTION}

$\mathbf{T}$ HE genus Galium L. (Rubiaceae) is a large and cosmopolitan genus comprising more than 600 species. They can be divided into subshrubs, perennials and annual herbs, and often have weak, creeping, prickly stems, whorled leaves and terminal and/or axillary inflorescences, that are thyrsoid to paniculiform or subcapitate in shape. The flowers are mostly bisexual, usually with a reduced calyx and a white, yellow to green corolla, commonly divided into four lobes. ${ }^{[1]}$ In Croatia, about 40 species have been reported, ${ }^{[2]}$ with quite a few of them found in the Šibenik area. [3]

Many members from the genus Galium and/or family Rubiaceae have been used as healing agents in folk medicine, including G. album Mill., ${ }^{[4]} G$. aparine L., ${ }^{[5,6]} G$. asperifolium Wall.,[6] Cruciata glabra (L.) Ehrend. (syn. Galium vernum Scop.), C. laevipes Opiz (syn. G. cruciata (L.) Scop.), G. Iucidum All., [5] G. mollugo L., ${ }^{[7]}$ G. odoratum (L.) Scop., ${ }^{[5]}$ G. rotundifolium L., ${ }^{[6]}$ and G. verum L. ${ }^{[4,5]}$ Considering their bioactive constituents, species from this genus are characterized by iridoids, ${ }^{[8,9]}$ phenolic acids, flavonoids, phytosterols ${ }^{[8]}$ and triterpenes, ${ }^{[8,9]}$ saponins, ${ }^{[9]}$ anthraquinones, coumarins, tannins and organic acids. ${ }^{[10]}$ Recent findings suggest different Galium species may possess potentially interesting biological activities, such as hepatoprotective, ${ }^{[11]}$ antidiabetic, ${ }^{[12]}$ antimicrobial, ${ }^{[13]}$ cytotoxic, ${ }^{[14]}$ burn healing, ${ }^{[15]}$ and antioxidant. ${ }^{[13-16]}$

Antioxidants play an important role in the prevention of oxidative stress. Having in mind the rising incidence of oxidative stress related diseases, such as cardiovascular and malignant diseases or diabetes, as well as the potentially negative consequences of using synthetic antioxidants, contemporary medicine turns more and more to plants as sources of natural antioxidants. ${ }^{[16]}$ The aim of this study was to qualitatively and quantitatively compare the bioactive compounds and examine the antioxidant activity of several representatives from the genus Galium, in order to evaluate their biomedical potential. Despite the widespread presence of these species in the world and their medicinal use in folk medicine, as well as various biological activities reported, ${ }^{[17]}$ data on the contents of major bioactive constituents and antioxidant capacity seem to be lacking for most Galium species. The present study

(c) Br Br 
was conducted on four Galium species with noted medicinal applications (G. cruciata, G. lucidum, G. mollugo and $G$. verum $)^{[4,5,7]}$ and four additional species ( $G$. corrudifolium, $G$. divaricatum, $G$. palustre and $G$. parisiense) that were simultaneously collected from natural populations located in the same climatic area. Qualitative screening tests were done for flavonoids, iridoids, tannins, saponins, anthraquinones, cardiac glycosides, triterpenes and steroids, while total phenolics, flavonoids and iridoids were quantified as well. Antioxidant (antiradical) activity under in vitro conditions as well as the content of bioactive ingredients were tested spectrophotometrically. To our knowledge, similar studies on the selected Galium species, except for $G$. mollugo and $G$. verum, ${ }^{[13,16]}$ have not been carried out so far, making this study a unique and valuable contribution to the present knowledge of these species, especially due to its comparative approach.

\section{EXPERIMENTAL SECTION}

\section{Plant Material}

Aerial parts of eight species from the genus Galium ( $G$. corrudifolium Vill., G. cruciata (L.) Scop., G. divaricatum Lem., G. lucidum All., G. mollugo L., G. palustre L., G. parisiense L., and G. verum L.), were collected during flowering season in June 2012 from Šibenik area. The identification was performed by Dr. Milenko Milović. Voucher specimens were deposited in the Herbarium of the Department of Pharmaceutical Botany, Faculty of Pharmacy and Biochemistry, University of Zagreb, Croatia.

\section{Plant Extracts}

Dried powdered aerial parts $(1.0 \mathrm{~g})$ were extracted two times for 30 minutes with $80 \%(\mathrm{v} / \mathrm{v})$ methanol $(10 \mathrm{~mL})$ using an ultrasonic bath (Bandelin Sonorex Super, Bandelin Electronic GmbH \& Co., Germany). After filtration through filter paper and a thin layer of cotton wool, the extracts were evaporated using a rotary vacuum evaporator (Büchi Rotavapor R-200, Büchi, Germany) at $50{ }^{\circ} \mathrm{C}$. The obtained resinous residues were held in a desiccator for two days and were afterwards weighed and re-dissolved in $80 \%(\mathrm{v} / \mathrm{v})$ methanol. Prepared solutions were quantitatively tranferred to $50 \mathrm{~mL}$ volumetric flasks and filled up to 50.0 $\mathrm{mL}$ with $80 \%(\mathrm{v} / \mathrm{v})$ methanol. Extracts were kept in polypropylene tubes at $2{ }^{\circ} \mathrm{C}$ until use. Extraction yield (\%) was calculated with regard to the dry weight of plant material used in the extraction.

\section{Phytochemical Screening}

Simple test tube reactions were conducted on $80 \%(v / v)$ methanol extracts or on powdered plant material to investigate the presence of flavonoids, tannins, saponins, anthraquinones, cardiac glycosides, iridoids, steroids and triterpenes, according to standard methods. ${ }^{[18-21]}$

\section{Total Phenolic and Flavonoid Content Determination}

Determinations of total phenolic and flavonoid content were done on a Varian Cary 50 Bio UV/Vis spectrophotometer (Varian Inc., USA) as previously described, [22] using the Folin-Ciocalteu method and $\mathrm{AlCl}_{3}$ method, respectively. Results are presented as $\mathrm{mg}$ gallic acid equivalents $\mathrm{g}^{-1}$ dry extract and $\mathrm{mg}$ quercetin equivalents $\mathrm{g}^{-1}$ dry extract, respectively.

\section{Iridoid Content Determination}

Quantitative analysis of iridoids was conducted according to Tundis et al. ${ }^{[23]}$ Results are presented as mg aucubin equivalents $\mathrm{g}^{-1}$ dry extract.

\section{Antioxidant Activity Assays}

Antioxidant activity was determined by the modified $2,2^{\prime}$ azino-bis(3-ethylbenzothiazoline-6-sulfonic acid) (ABTS) test, ${ }^{[24]}$ and 1,1-diphenyl-2-picrylhydrazyl (DPPH) test. ${ }^{[25]}$ Sixteen hours after mixing the ABTS (Sigma-Aldrich, USA) solution with $\mathrm{K}_{2} \mathrm{~S}_{2} \mathrm{O}_{8}$ (Kemika, Croatia) to final concentrations of $7.08 \mathrm{mmol} \mathrm{L}^{-1}$ and $2.56 \mathrm{mmol} \mathrm{L}^{-1}$, the obtained ABTS ${ }^{\bullet-}$ radical solution was diluted with $95 \%(v / v)$ ethanol until the moment when adding $80 \%(\mathrm{v} / \mathrm{v})$ methanol (100 $\mu \mathrm{L}$ ) to $1900 \mu \mathrm{L}$ of the diluted solution gave the absorbance of $0.70 \pm 0.02\left(A_{0}\right)$ at $734 \mathrm{~nm}$. Two-fold serially diluted samples $(100 \mu \mathrm{L})$ were mixed with $1900 \mu \mathrm{L}$ ABTS $^{-}$and the absorbance was measured after $1 \mathrm{~min}$ at $734 \mathrm{~nm}(\mathrm{~A})$, against an ethanol $95 \%(v / v)$ blank. Similarly, freshly prepared methanolic solution of DPPH (Fluka, Switzerland) was prepared in such a way to obtain the absorbance of $0.70 \pm 0.02\left(A_{0}\right)$ at $515 \mathrm{~nm}$ after mixing $80 \%(\mathrm{v} / \mathrm{v})$ methanol $(100 \mu \mathrm{L})$ with $1900 \mu \mathrm{L}$ of the DPPH solution. The absorbance was measured at $515 \mathrm{~nm}(\mathrm{~A})$, against a methanol blank, 30 min after mixing $1900 \mu \mathrm{L}$ of DPPH and $100 \mu \mathrm{L}$ of two-fold serially diluted samples. In both tests, percentage of absorbance reduction was obtained according to the following formula: $\left[\left(A_{0}-A\right) / A_{0}\right] \times 100$, where $A_{0}$ was absorbance of the control solution and $A$ was absorbance of the sample solution. Antiradical capacity is presented as $\mathrm{IC}_{50}\left(\mu \mathrm{g} \mathrm{mL}^{-1}\right)$, sample concentration that results in a $50 \%$ reduction of the free radical (ABTS or DPPH) absorbance.

\section{Statistical Analysis}

All spectrophotometric evaluations were performed in triplicate. The results are expressed as mean values \pm standard deviations. Differences among species were determined by one-way analysis of variance (ANOVA), followed by Tukey's post-hoc test, using GraphPad Prism 6.01 for Windows (GraphPad Software, San Diego, USA). 
The D'Agostino-Pearson omnibus normality test was applied to examine the normality of distribution. The correlation between different parameters was evaluated by Pearson's correlation coefficient $(r)$. Differences at $\mathrm{P}<$ 0.05 were considered statistically significant.

\section{RESULTS AND DISCUSSION}

All investigated species gave positive reactions for flavonoids and iridoids, while all species except G. lucidum and $G$. mollugo gave positive reactions for tannins (Table 1). Saponins, steroids and triterpenes were found in all species, except in G. Iucidum and G. corrudifolium. Interestingly, the above mentioned exceptions, which seemed to be relatively poor in bioactive substances, are members of the same section, Galium sect. Leiogalium. ${ }^{[26]}$

Lower extraction yields were obtained for the same three species (G. corrudifolium, G. lucidum, G. mollugo), whereby G. lucidum, the one with seemingly least diverse components, had the lowest extraction yield (8.1\%)
(Table 2). The peculiarity of this species arose previously in the comparison of leaf fatty acid composition among a number of Galium species, including the majority covered by the present study. ${ }^{[27]}$ On the other hand, the highest extraction yields were obtained for $G$. palustre $(20.5 \%)$ and G. parisiense (20.6\%), followed by G. verum (18.0\%) (Table 2). With this in mind, ultrasound assisted extraction seemed to be a fast and efficient method of extract preparation, more favorable than long lasting maceration, at least in the case of G. verum. ${ }^{[28]}$ The latter species was previously known to contain flavonoids, iridoids, triterpenes, sterols, ${ }^{[8]}$ tannins, and saponins, ${ }^{[29]}$ as shown by the present study (Table 1). The same positive reactions were recorded for $G$. cruciata, G. divaricatum, G. palustre and $G$. parisiense, with $G$. divaricatum showing the greatest similarity to G. verum. According to a previous study, aerial parts of $G$. odoratum are also rich in flavonoids and tannins, and contain saponins as well as anthraquinones. ${ }^{[15]}$ However, the presence of anthraquinones was not established in investigated samples, which could be due to

Table 1. Phytochemical screening results for investigated Galium spp.

\begin{tabular}{|c|c|c|c|c|c|c|c|}
\hline Species & Flavonoids(a) & Tannins & Saponins & Anthraquinones & $\begin{array}{c}\text { Cardiac } \\
\text { glycosides }\end{array}$ & Iridoids & $\begin{array}{c}\text { Steroids/ } \\
\text { triterpenes }\end{array}$ \\
\hline G. corrudifolium & ++ & + & - & - & - & $+/-$ & - \\
\hline G. cruciata & ++ & + & + & - & - & + & + \\
\hline G. divaricatum & ++ & ++ & + & - & - & ++ & ++ \\
\hline G. lucidum & + & - & - & - & - & + & - \\
\hline G. mollugo & + & - & + & - & - & + & + \\
\hline G. palustre & ++ & ++ & ++ & - & - & ++ & ++ \\
\hline G. parisiense & ++ & + & ++ & - & - & ++ & ++ \\
\hline G. verum & ++ & ++ & + & - & - & ++ & ++ \\
\hline
\end{tabular}

(a) - negative reaction, +/- weak positive reaction, + positive reaction, ++ strong positive reaction.

Table 2. Extraction yields together with total phenolic, flavonoid and iridoid contents of Galium spp. extracts

\begin{tabular}{|c|c|c|c|c|}
\hline Species & Yield / \% & Total phenolics ${ }^{(a)}$ & Flavonoids $^{(b)}$ & Iridoids ${ }^{(c)}$ \\
\hline G. corrudifolium & 10.7 & $93.23 \pm 2.71^{b}$ & $5.80 \pm 0.45^{f}$ & $141.99 \pm 4.90^{c}$ \\
\hline G. cruciata & 12.4 & $111.00 \pm 1.42^{\mathrm{a}}$ & $15.43 \pm 0.29^{d}$ & $58.78 \pm 2.05^{d}$ \\
\hline G. divaricatum & 17.3 & $78.98 \pm 2.55^{d}$ & $18.16 \pm 0.35^{c}$ & $308.36 \pm 24.90^{b}$ \\
\hline G. lucidum & 8.1 & $69.26 \pm 2.31^{\mathrm{e}}$ & $4.04 \pm 0.05^{g}$ & $109.35 \pm 4.80^{c}$ \\
\hline G. mollugo & 10.6 & $77.02 \pm 2.28^{d}$ & $10.30 \pm 0.16^{e}$ & $119.64 \pm 3.62^{c}$ \\
\hline G. palustre & 20.5 & $82.09 \pm 3.29 \mathrm{~cd}$ & $20.04 \pm 0.74^{b}$ & $279.80 \pm 13.31^{b}$ \\
\hline G. parisiense & 20.6 & $61.46 \pm 0.72^{f}$ & $2.40 \pm 0.25^{h}$ & $285.15 \pm 6.91^{b}$ \\
\hline G. verum & 18.0 & $86.40 \pm 1.74^{c}$ & $23.11 \pm 0.12^{a}$ & $461.30 \pm 14.68^{a}$ \\
\hline
\end{tabular}

The results are presented as mean values \pm standard deviations of replicate measurements $(n=3)$. Different superscript letters indicate significant differences among species in each column $(P<0.05)$.

(a) The values are expressed as $\mathrm{mg}$ gallic acid equivalents $\mathrm{g}^{-1}$ dry extract.

(b) The values are expressed as $\mathrm{mg}$ quercetin equivalents $\mathrm{g}^{-1}$ dry extract.

(c) The values are expressed as $\mathrm{mg}$ aucubin equivalents $\mathrm{g}^{-1}$ dry extract. 
the fact that they mostly occur in underground parts of Galium species. ${ }^{[30]}$

The amounts of bioactive constituents (total phenolics, flavonoids and iridoids) were determined in triplicate and the results are expressed as mean values and standard deviations (Table 2). Total phenolic contents varied between 61.46 and $111.00 \mathrm{mg}$ gallic acid equivalents $\mathrm{g}^{-1}$ dry extract. The greatest amount of total phenolics was found in $G$. cruciata $(P<0.05)$, which is now considered a member of a distinct genus (Cruciata), ${ }^{[2]}$ followed by the species: G. corrudifolium, G. verum, G. palustre and $G$. divaricatum. The lowest total phenolic content was recorded for $G$. parisiense $(P<0.05)$. According to obtained results, $G$. mollugo was among the species that were poorer in phenolic compounds (77.02 mg gallic acid equivalents $\mathrm{g}^{-1}$ dry extract). However, much greater total phenolic content was reported for a $50 \%(\mathrm{v} / \mathrm{v})$ ethanolic extract obtained from the aerial parts of the same species. ${ }^{[31]}$ In the present study, differences in the total phenolic content among Galium species were not as pronounced. On the other hand, differences in their flavonoid content were much stronger, thus suggesting that some species may have higher proportion of other polyphenolic compounds, such as phenolic acids. This is also supported by the results of an earlier phytochemical analysis of $G$. mollugo and $G$. verum, according to which the first species contained more phenolic acids (caffeic and chlorogenic acid) and the latter more flavonoids. ${ }^{[32]}$

Flavonoid contents varied from 2.40 to $23.11 \mathrm{mg}$ quercetin equivalents $\mathrm{g}^{-1}$ dry extract (Table 2 ). The greatest content was observed in $G$. verum $(P<0.05)$, followed by $G$. palustre, G. divaricatum and G. cruciata. According to a recent study, G. mollugo may contain more phenolic compounds and flavonoids than $G$. verum and related species. ${ }^{[13]}$ However, in the present study, G. verum, which is a member of the $G$. sect. Galium, ${ }^{[26]}$ contained more than double the amount of flavonoids in comparison to $G$. mollugo (10.30 mg quercetin equivalents $\mathrm{g}^{-1}$ dry extract), member of the $G$. sect. Leiogalium, ${ }^{[26]}$ which corresponds to earlier observations. ${ }^{[32]} A$ similar relationship was also observed in a study comparing the same species to $G$. album, ${ }^{[8]}$ another representative of the $G$. sect. Leiogalium. ${ }^{[26]} \mathrm{G}$. verum was found to be especially rich in rutin, ${ }^{[8,13]}$ a flavonoid common to all Galium species. Many species from this genus, including the investigated $G$. palustre, G. mollugo and G. verum, share additional flavonoids such as isorhoifolin, palustroside and cosmosiin, while even more flavonoids seem to be shared by the last two species. ${ }^{[33]}$ This is in line with their much closer relationship compared to $G$. palustre ( $G$. sect. Aparinoides).[26] Naturally, as members of different sections, $G$. mollugo and $G$. verum may contain their own distinctive flavonoids. ${ }^{[13,32,33]}$ The spectrophotometric results, however, were not completely consistent with the results of qualitative phytochemical analyses (Table 1). For instance, G. parisiense, contained least flavonoids according to the spectrophotometric assay, while in the phytochemical screening based on a simple color reaction with sodium hydrogen it was not remarkably different from the species in which much higher flavonoid concentrations were recorded. The observed discrepancies might be consequences of false positive reactions with coumarins, which may give yellow coloration with sodium hydrogen, ${ }^{[34]}$ which was used for the qualitative analysis, or of false negative reaction in the quantification with aluminum chloride, due to absence/reduced complexation of flavons and flavonols glycosylated or methoxylated at $C-3, C-5, C-3^{\prime}$ and $C-4$ ' position. ${ }^{[35]}$

Iridoid content varied between $58.78 \mathrm{mg}$ aucubin equivalents $\mathrm{g}^{-1}$ dry extract in $G$. cruciata and $461.30 \mathrm{mg}$ aucubin equivalents $\mathrm{g}^{-1}$ dry extract in $G$. verum (Table 2 ). The latter species had three to four times more iridoids than investigated species from the $G$. sect. Leiogalium ( $G$. corrudifolium, G. lucidum and $G$. mollugo), thus supporting earlier findings. ${ }^{[8]}$ In fact, comparing to other Galium species, $G$. verum seems to be especially rich in asperuloside, ${ }^{[36]}$ an iridoid glucoside that gives blue coloration (positive reaction) with the Trim-Hill reagent. ${ }^{[18]}$ A higher amount of the same compound was also found in species such as $G$. palustre and $G$. divaricatum. ${ }^{[36]}$ According to our results, the two species, together with $G$. parisiense, seem to be among the species rich in iridoids, and $G$. divaricatum and $G$. parisiense actually belong to the same section (G. sect. Kolgyda). ${ }^{[26]}$ According to the previous study, the iridoid pattern of $G$. palustre seems to be similar to that of $G$. verum. ${ }^{[36]}$ The results obtained in the present study also indicate that they share a similar phenolic and flavonoid content. This may be connected to the fact that they were harvested from the same location. On the other hand, the low iridoid content recorded for $C$. laevipes (syn. G. cruciata) may indicate a distinct iridoid pattern. The major iridoid component found in this species was deacetylasperulosidic acid, which was accompanied by other iridoids (scandoside, asperuloside, asperulosidic acid, deacetylasperulosidic acid methyl ester and daphylloside) and coumarins. ${ }^{[37]}$

Antioxidant activity was determined by the DPPH and the ABTS tests, based on antiradical capacity, that are commonly used for evaluation of antioxidant activities in vitro of natural compounds. ${ }^{[38]}$ Both methods have been previously used for the investigation of antioxidant (antiradical) potential of species from the genus Galium, with the DPPH test being much preferred. ${ }^{[13-16,31,39,40]}$ In our study, very good positive correlation was found between the two methods ( $r=0.93, \mathrm{P}=0.001$ ) (Table 3). According to obtained results, all investigated species possess 
Table 3. Pearson's correlation coefficients $(r)$ between investigated parameters (total phenolic content, flavonoid content, iridoid content, DPPH radical scavenging capacity and ABTS radical scavenging capacity)

\begin{tabular}{lcccc}
\hline & Flavonoids & DPPH & Iridoids & ABTS \\
\hline Total phenolics & $0.44(0.276)$ & $-0.29(0.483)$ & $-0.64(0.089)$ & $-0.73(0.041)$ \\
Flavonoids & - & $0.55(0.163)$ & $-0.76(0.028)$ & $-0.81(0.014)$ \\
Iridoids & $0.55(0.163)$ & $-0.41(0.311)$ & $-0.25(0.556)$ & $-0.93(0.001)$ \\
DPPH & $-0.76(0.028)$ & $-0.41(0.311)$ & $0.93(0.001)$ & - \\
ABTS & $-0.81(0.014)$ & $-0.25(0.556)$ & & - \\
\hline
\end{tabular}

(a) Numbers in brackets represent $\mathrm{P}$ values for each $r$.

antiradical properties (Figure 1). The best antiradical capacity was shown by G. cruciata, G. divaricatum and $G$. verum, with the following values obtained: $\mathrm{IC}_{50}=30.30 \mu \mathrm{g}$ $\mathrm{mL}^{-1}, 34.65 \mu \mathrm{g} \mathrm{mL}^{-1}$ and $36.70 \mu \mathrm{g} \mathrm{mL}^{-1}$ in the ABTS test, IC $\mathrm{C}_{50}$ $=27.62 \mu \mathrm{g} \mathrm{mL}-1,30.30 \mu \mathrm{g} \mathrm{mL}^{-1}$ and $30.72 \mu \mathrm{g} \mathrm{mL}^{-1}$ in the DPPH test. Previous studies of antioxidant activities of extracts obtained from Galium species showed a similar trend, ${ }^{[39]}$ with lower $I C_{50}$ values established in the DPPH test. ${ }^{[40]}$ Lower values observed in the test using the DPPH free radical may be a result of its greater sensitivity to reaction conditions, as for example the $\mathrm{pH}$ of the reaction mixture, to whose changes the ABTS radical cation is less susceptible. ${ }^{[38]}$ Similar to the results of the present study, greater DPPH free radical scavenging activity was recently recorded for the $70 \%(\mathrm{v} / \mathrm{v})$ ethanolic extract of $\mathrm{G}$. verum compared to the same activities of related Galium species. ${ }^{[13]}$ Furthermore, the somewhat greater antioxidant effect observed in the present study for $G$. cruciata corresponds to the results previously obtained for related Cruciata taurica (Pall. ex Willd.) Ehrend. and G. verum. ${ }^{[16]}$ Finally, the $\mathrm{IC}_{50}$ values obtained for the $G$. mollugo extract were comparable to those reported previously for the $50 \%$ $(v / v)$ ethanolic extract of its aerial parts $\left(\mathrm{IC}_{50}=45-62 \mu \mathrm{g}\right.$ $\mathrm{mL}^{-1}$ ), where better activity was shown by samples containing higher total phenolic and flavonoid content. ${ }^{[31]}$

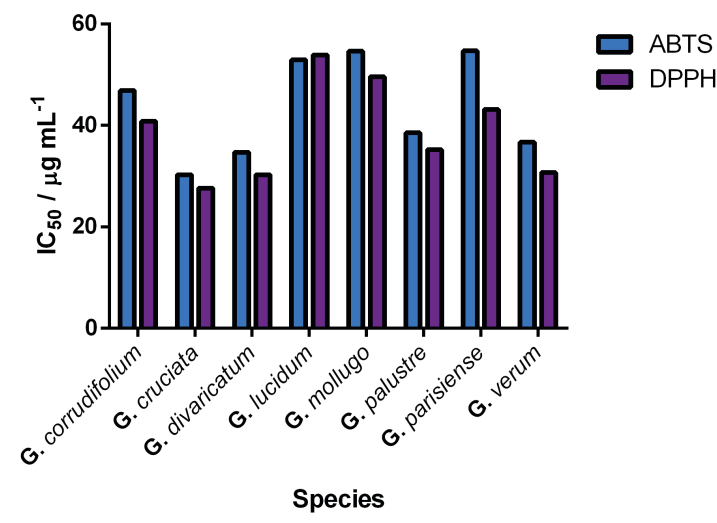

Figure 1. Antiradical capacity of Galium spp. extracts.
In the present study, very good negative correlations were observed between flavonoid content and antiradical capacity results obtained in the ABTS radical scavenging assay $(r=-0.81, \mathrm{P}=0.014)$ and the DPPH radical scavenging assay $(r=-0.76, \mathrm{P}=0.028$ ) (Table 3 ). A significant negative correlation was also observed between total phenolic content and ABTS radical scavenging assay results $(r=-0.73$, $P=0.041)$, while the correlation found between total phenolic content and DPPH radical scavenging assay results was not significant $(r=-0.64, \mathrm{P}=0.089)$. These results suggest that antiradical capacities of selected Galium species are highly dependent on their flavonoid levels. Rutin (quercetin 3-O-rutinoside), being not only a common flavonoid of Galium species, ${ }^{[33]}$ but also the predominant one, ${ }^{[13]}$ might have contributed to the observed activity to a greater extent. However, according to recent findings, rutin values in $G$. verum can greatly exceed those in $G$. mollugo and related species such as $G$. aparine and $G$. odoratum, ${ }^{[13]}$ members of the $G$. sect. Kolgyda and G. sect. Hylaea, ${ }^{[26]}$ which were not included in our study, while the DPPH free radical scavenging capacities, especially of the first two species, do not seem to follow the same pattern. ${ }^{[13]}$ This indicates that other flavonoid compounds with even greater antiradical potential than rutin may be present in these extracts. Some of them might be quercetin, which was recorded as the second major flavonoid in $G$. aparine, and its derivative quercitrin (quercetin 3-O-rhamnoside), recorded as the second major flavonoid in $G$. mollugo. ${ }^{[13]}$ Indeed, having in mind the greater DPPH and ABTS radical scavenging capacity of quercetin in comparison to rutin, most likely attributable to the steric hindrance of the latter compound, ${ }^{[41]}$ presence of the former compound might be responsible for the high antiradical capacity of $G$. divaricatum recorded in our study, considering that this species belongs to the same section as G. aparine. ${ }^{[26]}$ Also, the antiradical capacities of G. verum, G. mollugo and $G$. odoratum, established in the previously conducted DPPH test $\left(\mathrm{IC}_{50}=105.43 \mu \mathrm{g} \mathrm{mL}-1, \mathrm{IC}_{50}=107.45\right.$ $\mu \mathrm{g} \mathrm{mL}^{-1}$ and $\mathrm{IC}_{50}=264.42 \mu \mathrm{g} \mathrm{mL}^{-1}$, respectively), seem to reflect the relationships of quercitrin content between the same species, while isoquercitrin (quercetin 3-O-glucoside), 
although an important component of G. verum extract, seems to be less important for the observed activity. ${ }^{[13]}$ This assumption is supported by recent findings, according to which a higher $\mathrm{IC}_{50}$ value for isoquercitrin in the DPPH test may be attributable to the adverse effect that its $6^{\prime \prime}-\mathrm{OH}$ group has, via steric hindrance or $\mathrm{H}$-bonding, on the $\mathrm{H}$ donating ability of the phenolic - $\mathrm{OH}$ groups in the $\mathrm{A}$ and $\mathrm{B}$ rings. Conversely, absence of the same group in quercitrin facilitates the formation of stable DPPH-H molecules. ${ }^{[42]}$

On the other hand, certain phenolic compounds, such as phenolic acids, seem to be of less importance for the antioxidant activity. G. odoratum, a species that showed much weaker antiradical capacity in a previous study, ${ }^{[13]}$ was found to contain much greater amounts of phenolic acids, especially chlorogenic acid, compared to related species ${ }^{[3]}$ with more pronounced antiradical capacities.[13] However, the highest amount of total phenolics was observed for $G$. cruciata $(P<0.05)$ (Table 2), the species with the best antiradical capacity, thus indicating that it may be rich in distinctive phenolic compounds with great antioxidant potential. As already mentioned, according to more recent classifications, the species is considered to belong to a distinct genus Cruciata (C. laevipes). ${ }^{[26,44]}$ Species from the genus Cruciata are mainly characterized by presence of coumarins and iridoids, whereby the major coumarins daphnin and daphnetin glucoside, ${ }^{[37,44]}$ which seem to be lacking in species from the genus Galium ${ }^{[44]}$ do, in fact, contain a phenolic group in their structure. ${ }^{[37]}$ Phenolic coumarins, including the aglycone of the two coumarins previously mentioned (daphnetin), were reported to possess considerable antioxidant activities against free radicals such as DPPH, ABTS and other, which may be stronger than those of caffeic acid. ${ }^{[45]}$ Moreover, values of $I_{50}$ observed in the DPPH test for methanolic extracts of species from the genus Daphne, having the same major compound, were close to those found in our study for G. cruciata. ${ }^{[46,47]}$ Finally, no correlation was observed between antiradical capacity and iridoid content $(P>0.05)$ (Table 3). Although being the major constituents of most of the studied species (Table 2), iridoids, that are most likely largely represented by asperuloside (Galium) ${ }^{[36]}$ and deacetylasperulosidic acid (Cruciata), ${ }^{[37]}$ do not seem to contribute to the observed antiradical activity in a significant way.

\section{CONCLUSION}

Total phenolic, flavonoid and iridoid content of $G$. corrudifolium, G. cruciata, G. divaricatum, G. lucidum, G. palustre and $G$. parisiense, as well as their antioxidant (antiradical) capacity, were evaluated for the first time, together with those of known medicinal plants G. mollugo and $G$. verum, that had been previously explored in a similar way. These investigations were preceded by qualitative phytochemical screening reactions conducted on all investigated species. The highest contents of total phenolics and flavonoids, as well as greatest antioxidant activities were observed for G. cruciata, G. divaricatum, G. palustre and G. verum. The same species were also rich in other bioactive compounds and, therefore, show potential for further investigations. Members of the Galium sect. Leiogalium (e.g. G. mollugo) were relatively poor in bioactive substances, thus confirming previous findings. Our results suggest that the used tests, when done on a larger number of closely related species, may provide a good starting point in gaining chemotaxonomically useful information.

Acknowledgment. This research was supported by the Ministry of Science, Education and Sports of the Republic of Croatia (project No. 006-0061117-1239).

\section{REFERENCES}

[1] C. Tao, F. Ehrendorfer, Fl. China 2011, 19, 104.

[2] T. Nikolić, Flora Croatica Database, 2018. On-Line (http://hirc.botanic.hr/fcd). Department of Botany, Faculty of Science, University of Zagreb.

[3] M. Milović, Nat. Croat. 2002, 11, 171.

[4] A. Pieroni, C. L. Quave, J. Ethnopharmacol. 2005, 101, 258.

[5] D. Zahariev, L. Taneva, K. Racheva, Acta Sci. Naturalis 2015, 2, 99.

[6] P. Sharma, S. S. Samant, Asian J. Adv. Basic Sci. 2014, $2,77$.

[7] S. Jarić, M. Mitrović, B. Karadžić, O. Kostić, L. Djurjević, M. Pavlović, P. Pavlović, Genet. Res. Crop Evol. 2014, 61, 1359.

[8] G. Ghiță, R. Necula, A. Trifan, E. Gille, M. M. Zamfirache, U. Stănescu, Ann. Univ. Stiint. Iasi Biol. Veget. 2012, 58, 45.

[9] M. I. Mitova, M. E. Anchev, N. V. Handjieva, S. S. Popov, Z. Naturforsch. C 2002, 57, 226.

[10] J. A. Duke, Handbook of phytochemical constituents of GRAS herbs and other economic plants, CRC Press, Boca Raton-London-New York-Washington, D.C., 1992, p. 263.

[11] O. V. Goryacha, T. V. Ilyina, A. M. Kovalyova, O. M. Koshovyi, O. V. Krivoruchko, I. M. Vladimirova, A. M. Komisarenko, Der Pharma Chem. 2017, 9, 80.

[12] S. T. Khan, M. Ahmed, R. A. Khan, N. Mushtaq, N. Khan, Trop. J. Pharm. Res. 2017, 16, 1573.

[13] L. Vlase, A. Mocan, D. Hanganu, D. Benedec, A. Gheldiu, G. Crișan, Dig. J. Nanomater. Biostruct. 2014, 9, 1085.

[14] Ö. S. Aslantürk, T. A. Çelik, B. Karabey, F. Karabey, Br. J. Pharm. Res. 2017, 15, 1. 
[15] N. Kahkeshani, B. Farahanikia, P. Mahdaviani, A. Abdolghaffari, G. Hassanzadeh, M. Abdollahi, M. Khanavi, Res. Pharm. Sci. 2013, 8, 197.

[16] A. Mavi, Z. Terzi, U. Özgen, A. Yildirim, M. Coşkun, Biol. Pharm. Bull. 2004, 27, 702.

[17] M. Friščić, M. Štibrić Baglama, M. Milović, K. Hazler Pilepić, Ž. Maleš, Farm. Glas. 2018, 74, 343.

[18] J. B. Harborne, Phytochemical methods, Chapman and Hall, London-New York, 1973, pp. 119-120.

[19] S. E. Okhale, H. O. Egharevba, E. C. Ona, O. F. Kunle, J. Med. Plants Res. 2012, 6, 2289.

[20] M. N. Abbas, S. A. Rana, M. Shahid, N. Rana, M. Mahmood-ul-Hassan, M. Hussain, J. Anim. Plant Sci. 2012, 22, 283.

[21] G. N. Anyasor, K. O. Ogunwenmo, O. A. Oyelana, B. E. Akpofunure, Afr. J. Biotechnol. 2010, 9, 4880.

[22] D. Khlifi, M. Hamdi, A. El Hayouni, S. Cazaux, J. P. Souchard, F. Couderc, J. Bouajila, Molecules 2011, 16, 10592.

[23] R. Tundis, M. Bonesi, F. Menichini, M. R. Loizzo, F. Conforti, G. Statti, F. M. Pirisi, F. Menichini, Nat. Prod. Commun. 2012, 7, 1015.

[24] R. Re, N. Pellegrini, A. Proteggente, A. Pannala, M. Yang, C. Rice-Evans, Free Radic. Biol. Med. 1999, 26 1231.

[25] C. Thetsrimuang, S. Khammuang, R. Sarnthima, Int. J. Pharmacol. 2011, 7, 58.

[26] V. L. Soza, R. G. Olmstead, Taxon 2010, 59, 755.

[27] S. Mongrand, A. Badoc, B. Patouille, C. Lacomblez, M. Chavent, J. J. Bessoule, Phytochemistry 2005, 66, 549.

[28] N. S. Lakić, N. M. Mimica-Dukić, J. M. Isak, B. N. Božin, Cent. Eur. J. Biol. 2010, 5, 331.

[29] K. Toplak Galle, Domaće ljekovito bilje, Mozaik knjiga, Zagreb, 2005, pp. 114-115.

[30] J. Kuiper, R. P. Labadie, Planta Med. 1981, 42, 390.

[31] P. S. Milić, L. P. Stanojević, K. M. Rajković, S. M. Milić, V. D. Nikolić, LJ. B. Nikolić, V. B. Veljković, Hem. Ind. 2013, 67, 89.
[32] M. Tămaş, D. Stana, S. Timiş, Not. Bot. Horti Agrobot. Cluj-Napoca 2006, 34, 18.

[33] T. V. Ilyina, O.V. Goryacha, A. M. Kovaleva, O. M. Koshovyi, I. L. Shinkovenko, Pharm. Lett. 2016, 8, 316.

[34] M. Deyab, T. Elkatony, F. Ward, Int. J. Eng. Develop. Res. 2016, 4, 674.

[35] D. Mammen, M. Daniel, Food Chem. 2012, 135, 1365.

[36] R. Taskova, M. Mitova, L. Evstatieva, M. Ančev, D. Peev, N. Handjieva, V. Bankova, S. Popov, Bocconea 1997, 5, 631 .

[37] M. I. Mitova, M. E. Anchev, S. G. Panev, N. V. Handjieva, S. S. Popov, Z. Naturforsch. C 1996, 51, 631.

[38] E. A. Shalaby, S. M. M. Shanab, Indian J. Geomarine Sci. 2013, 42, 556.

[39] V. D. Mitic, V. P. Stankov-Jovanovic, M. D. Ilic, P. J. Vasiljevic, A. LJ. Zabar, G. S. Stojanovic, Bulg. Chem. Commun. 2014, 46, 269.

[40] J. Bokhari, M. R. Khan, M. Shabbir, U. Rashid, S. Jan, J. A. Zai, Spectrochim. Acta Mol. Biomol. Spectrosc. 2013, 102, 24

[41] D. Rusmana, R. Wahyudianingsih, M. Elisabeth, B. Balqis, M. Maesaroh, W. Widowati, Indones. Biomed. J. 2017, 9, 84

[42] X. Li, Q. Jiang, T. Wang, J. Liu, D. Chen, Molecules 2016, 21, 1246.

[43] A. Mocan, G. Crișan, L. Vlase, B. Ivănescu, A. S. Bădărău, A. L. Arsene, Farmacia 2016, 64, 95.

[44] D. Martins, C. V. Nunez, Molecules 2015, 20, 13422.

[45] R. G. Shinde, A. A. Khan, A. Barik, Int. J. Med. App. Sci. 2014, 3, 165.

[46] N. T. Manojlović, P. Z. Mašković, P. J. Vasiljević, R. M. Jelić, M. Ž. Jusković, M. Sovrlić, L. Mandić, M. Radojković, Hem. Ind. 2012, 66, 709.

[47] M. Sovrlić, P. Vasiljević, M. Jušković, P. Mašković, N. Manojlović, Trop. J. Pharm. Res. 2015, 14, 1239. 